\title{
TWENTIETH WORLD RED CROSS DAY
}

In its issue for March 1967, the International Review pointed out the significance in 1967 of the World Day for the Red Cross, Red Crescent and Red Lion and Sun. We may now state that it was celebrated in many countries and that various events took place which we shall describe later. Today, we would merely say that the press, radio and television joined in the general effort, of which the aim, apart from paying tribute to Henry Dunant's memory, is to enable National Societies to make known their activities and participation in the world Red Cross movement.

The theme chosen, Protect health, prevent accidents, save lives through the Red Cross, implied that everybody could be trained in hygiene and first-aid and that, once trained, they could contribute effectively to the improvement of health. That is why an institution such as the World Health Organization once again associated in this World Red Cross Day. An address by its Director, Dr. M. G. Candau, clearly showed the immense scope for humanitarian activities:

Dr. A. Sauter, President of the World Health Assembly, pointed out that the meeting, as it happened, opened on May 8 and he took the opportunity to pay tribute to the Red Cross in his opening address:

By a favourable coincidence the date of our Assembly's opening session this year is the 8th of May which, as you know, is the anniversary of the birth in Geneva in 1828 of Henry Dunant, the founder of the Red Cross. Many of the delegates who are today in this town, the birthplace of the Red Cross, are also in touch with the Red Cross, Red Crescent and Red Lion and Sun Societies when they are in their own countries. It is no news to them, therefore, that for the past twenty years World Red Cross Day has been commemorated on the 8th of May. 


\section{IN THE Red Cross WorLd}

Nor need I remind them of the community of aims and close cooperation which exist between the World Health Organization and the Red Cross.

This year the World Health Organization is laying stress on teamwork by "partners in health", and it is significant that, when adopting the theme "Protect health; prevent accidents; save lives ..." for its World Day in 1967, the Red Cross chose a subject which highlights the achievements of well trained voluntary workers in action alongside professionals. They render signal service, particularly the younger set, in such fields as health in the home, at school and in the community, first-aid and the prevention of accidents and diseases. Allow me, on this World Red Cross Day, to pay tribute on behalf of this Assembly to the splendid movement of universal fellowship which has made possible the alleviation of so much human distress.

The World Red Cross Day at the Montreal Exhibition was officially commemorated before a large attendance including Mr. J. A. Broadbent, President of the Canadian Red Cross and General J. F. Collins, President of the American Red Cross. At eleven o'clock, the Red Cross colours were run up and many children from various parts of Canada raised flags from all the countries where our movement exists. Speeches were then made: Mr. Pierre Dupuy, the general commissioner of the Exhibition, after welcoming visitors, stressed the importance and moral significance of the signs of the red cross, red crescent and red lion and sun. Mr. José Barroso, Chairman of the League of Red Cross Societies, after recalling our movement's universality, said: "It is a great pleasure to be here in Canada, a country that serves not only itself but also looks to the welfare of others." Mr. Gonard, ICRC President, stated that the Red Cross flag was in evidence for the first time on a battlefield in Canada in 1885 when a young army doctor raised it above his ambulance in the course of fighting during the uprising in Saskatchewan. "Moreover", he added, "the theme of the Exhibition-Man's World-is close to the spirit of the Red Cross. As your late Governor-General, General Georges Vanier, stated, the aim of the Exhibition should be: One world, the world 
of Humanity; one race, the race of Man; one language, the language of Fraternity. These are also the aspirations of the Red Cross ".

On the same day, the first monument to the memory of Henry Dunant in Canada was inaugurated. It is at Laval, near Montreal, in a fine park, and during the ceremony, Mr. Gonard laid flowers on the monument on behalf of the International Red Cross. After mentioning the prophetic role of the author of $A$ Memory of Solferino, he paid the following tribute to the Canadian Red Cross:

Here, in front of our founder's monument, I wish to thank you, in the name of the International Committee of the Red Cross, whose duty it is in time of war to execute Dunant's ideals for the greater benefit of the victims, for all you have done, and are doing, to promote and develop Red Cross, at home and abroad.

Long may the Canadian Red Cross continue to serve our common cause : Humanity!

As already mentioned, the radio and television also took part in the celebration of this 20th World Red Cross Day.

The Swiss Broadcasting Corporation had been entrusted by the broadcasting corporations of other French-speaking countries (France, Canada, Belgium, Luxemburg, Monte Carlo) with the production of a programme on Red Cross activities throughout the world. This aimed at showing that the Red Cross principle of universality was reflected in the work carried out by the ICRC, the League and the National Societies, and that their activities often exceeded in scope and effectiveness the image which is all too prevalent.

Mr. J. P. Goretta, who directed this documentary, condensed into a twenty minute broadcast the testimony of Red Cross delegates who were in Vietnam, India and the Yemen on May 8, 1967. He accompanied an ICRC delegate on a visit to a prison camp in the region of Saigon. He recorded a moving account by a League delegate who on that day had just returned from one of the worst famine stricken areas of India. Through the ICRC radio station he made direct contact with one of the medical teams working in the mountains of the Yemen. 
These radio documentary reports once again showed the great diversity of Red Cross work and the difficulties which have to be faced by delegates carrying out their missions, frequently under exceptional conditions of isolation and at considerable risk.

The Swiss Television Corporation also broadcast a special programme entitled “ May 8, 1967 ”. This lasted for 25 minutes and was broadcast by eight European television transmitters in six languages: Belgium (Flemish and French), Luxembourg, Portugal, Spain and Switzerland (French, German and Italian). The programme included a film showing some Red Cross activities in Vietnam, the Yemen and several African countries (Liberia, Nigeria, Togo and Zambia). It showed the solid bond which exists among the various bodies of the International Red Cross, the ICRC, the League and the National Societies.

A number of National Societies have requested the Swiss Television Corporation to supply them with copies of this film.

As in previous years, a brief ceremony took place in Geneva on the morning of May 8 at the monument to Henry Dunant's memory in the Parc des Bastions. Among the many people attending the ceremony were representatives of official bodies as well as of the ICRC, the League and the Swiss Red Cross. Wreaths were laid on the monument by members of the Junior Red Cross; one of these bore the inscription "Les jeunes de la Croix-Rouge à Henry Dunant ". This event was impressive as a demonstration of youthful attachment to the founder of the Red Cross and to the ideal which he so perseveringly and effectively personified. Two addresses, one by Mr. J. P. Buensod, President of the Geneva Red Cross, and the other by Mr. C. A. Schusselé, Director of the League's Red Cross Youth Bureau, dwelt on the essential role incumbent on the younger generation if the humanitarian ideal is to prevail and develop in the world of the future. 